\title{
Effect of oestradiol $17 \beta$ combined with trembolone acetate on growth performances of fattening male kids
}

\author{
Ph. SCHMIDELY, P. MORAND-FEHR, P. BAS, J. HERVIEU
}

The aim of the experiment was to study the effect of anabolic agents on growth, carcass characteristics and body composition of kids receiving different kinds of diets.

Twelve Alpin or Saanen male kids were allocated in a $2 \times 2$ randomised block design as follows : at 7 days old, 6 kids were implanted with $20 \mathrm{mg}$ oestradiol $17 \beta+70 \mathrm{mg}$ TBA (treated group I), six kids were not implanted (Control group C). In each group, half of the kids received a milk substitute rich in Lactose (L) $(4320 \mathrm{kcal} \mathrm{ME} / \mathrm{kg}$ DM) and the other half, a milk substitute rich in fat $(\mathrm{G})(5070 \mathrm{kcal} \mathrm{ME} / \mathrm{kg} \mathrm{DM})$ ad libitum. They were slaughtered at 7 weeks of age. After chilling at $4^{\circ} \mathrm{C}$, the carcasses were cut following the method described by Colomer-Rocher et al. (1987). For each right leg, following constituents were separated: muscle, bone, subcutaneous and instramuscular fat, and wastes.

Implantation resulted in a non significant increase of body weight at 7 weekds old : 14.02, $15.22,14.57,13.38 \mathrm{~kg}$ respectively for the groups IG, IL, CG, CL, and a non significant increase of average daily gains : $225,247,238,208 \mathrm{~g}$. Treated animals ate $10 \% \mathrm{DM}$ less than control and had a better efficiency of feed utilization $(\mathrm{P}<0.01)(1.27,1.32,1.33,1.47 \mathrm{~kg} \mathrm{DM} / \mathrm{kg}$ ADG) and energy utilization for the growth $(5978,5613,6415,5950 \mathrm{kcal} \mathrm{ME} / \mathrm{kg} \mathrm{ADG})$. Kids receiving milk rich in lactose had a better efficiency of energy utilisation though they had a worse feed efficiency. This might be explained by the lowered weights of adipose tissue in the body (see below).

Cold carcass weights of implanted kids were higher than those of unimplanted kids $(\mathrm{P}<0.01)$. Their dressing percentage were better $(\mathrm{P}<0.05)(54.3,53.9,53.1,53.7 \mathrm{~kg}$ carcass $/ \mathrm{kg}$ live weight $\times 100)$. The weight of cuts having a high proportion of bone : neck, $(\mathrm{P}<0.01)$, ribs $(P<0.05)$, flank (NS) was higher. The cuts having a high proportion of muscle (shoulders and legs) were not modified by treatment, but leg weight tended to decrease : $31.1,31.9,32.4,32.2$ respectively (expressed in percent of cold carcass weight). The nature of diets did not significantly influence the proportions of the different cuts in the carcass. Fattening score [estimated by a note between 1 (very lean) and 5 (very fatty) $]$ was lower in treated kid carcasses $(\mathrm{P}<0.01)$ in kids given lactose rich milk : $2.91,2.20,3.65,3.34$. Conformation score was not modified.

When expressed as a percentage of the leg weight, subcutaneous fat was reduced by treatment $(P<0.05)$ and lactose rich milk (NS) : 2.95, 2.75, 2.20, 2.00 and intramuscular fat was decreased by implantation (NS) and lactose rich milk $(\mathrm{P}<0.05): 5.50,4.20,7.30,4.70$. Implantation $(\mathrm{P}<0.05)$ and lactose rich milk $(\mathrm{P}<0.05)$ also reduce the weight of perirenal adipose tissue : $132,80,190,98 \mathrm{~g}$ for the group IG, IL, CG and $\mathrm{CL}$ respectively.

Anabolic agents did not modify the proportions of muscle and bone and the muscle/bone ratio. However, anabolics increased the proportion of bone in the leg, which is in agreement with the results obtained in the carcass.

Implantation time is discussed in relation with optimal growth and body composition. For the production of kid carcasses, anabolics would be interesting to use because they improve feed efficiency but they reduce adipose tissues.

Key words: Anabolic agent, kid, oestradiol, trembolone, growth. 